\title{
Effects of thermal stress on early developmental stages of a gorgonian coral
}

\author{
Silvija Kipson ${ }^{1,2, *}$, Cristina Linares ${ }^{3}$, Núria Teixidó ${ }^{2,3}{ }^{\text {, }}$ Tatjana Bakran-Petricioli ${ }^{1}$, \\ Joaquim Garrabou ${ }^{2}$
}

\author{
${ }^{1}$ Division of Biology, Faculty of Science, University of Zagreb, 10000 Zagreb, Croatia \\ ${ }^{2}$ Institut de Ciències del Mar (ICM-CSIC), 08003 Barcelona, Spain \\ ${ }^{3}$ Departament d'Ecologia, Universitat de Barcelona, 08028 Barcelona, Spain
}

\begin{abstract}
Ongoing sea temperature increase threatens reefs worldwide. In this study we experimentally examined for the first time the response of the early life stages of a long-lived structural gorgonian, the Mediterranean species Paramuricea clavata (Risso 1826), to the highest summer temperature recorded so far in the study area $\left(25^{\circ} \mathrm{C}_{i}\right.$ the Medes Islands, Northwestern Mediterranean). This temperature also simulates the end-of-century predicted warming $\left(+3^{\circ} \mathrm{C}\right)$ over the temperature maxima recorded during the species' reproductive period. The results showed a severe negative impact of constant thermal stress on the viability of $P$. clavata embryos and larvae, resulting in reduced survivorship, completely abnormal embryonic development and impaired metamorphosis. The deteriorating effect was rapid for embryos (after $7 \mathrm{~h}$ ), whereas the impact on larvae became evident after $10 \mathrm{~d}$ of stress. Larval modifications started $7 \mathrm{~d}$ earlier under elevated temperature conditions, but the appearance of spherical, aberrant shapes prevented an assessment of whether metamorphosis was initiated but abnormal, or deterred altogether. The apparent higher sensitivity of embryos suggests that thermal stress during embryonic development may be the most critical factor for the viability of $P$. clavata larvae. In the context of an ongoing warming trend, the reduced viability of early life stages would jeopardize the persistence of $P$. clavata, which relies on successful recruitment for replenishment of its populations. Further research into the effects of thermal stress on the reproduction of structural invertebrate species and the viability of their early life stages will improve our understanding of the long-term consequences of environmental global change in marine benthic communities.
\end{abstract}

KEY WORDS: Temperature stress - Octocoral - Embryogenesis - Larval development · Mediterranean Sea $\cdot$ Global warming

Resale or republication not permitted without written consent of the publisher

\section{INTRODUCTION}

Marine communities are currently affected by several anthropogenic stressors, and warming is generally recognized as one of the most widespread threats (Halpern et al. 2008). An increasing number of studies focuses on the effects of elevated temperatures on the early life stages of scleractinian corals. These studies refer to altered developmental or metamorphosis rates, reduced respiration, abnormal morphologies, reduced pre-competency periods, de- creased settlement and changes in settlement behaviour, and reduced fitness and survivorship (Brooke \& Young 2005, Putnam et al. 2008, Randall \& Szmant 2009a and references therein, Heyward \& Negri 2010, Edmunds et al. 2011). More recently, several studies have used gene expression approaches to detect responses at a molecular level of both coral embryos and larvae subjected to elevated temperatures (e.g. Rodriguez-Lanetty et al. 2009, Voolstra et. al 2009, Polato et al. 2010, Portune et al. 2010). However, most of these studies examined the effects of 
elevated temperature on tropical or subtropical scleractinian corals, while data on octocorals and temperate corals are lacking (but see Zeevi-Ben-Yosef \& Benayahu 2008).

The Mediterranean region is considered to be among the main climate change hotspots (Giorgi 2006), where several mass mortality events of invertebrates, caused by positive seawater temperature anomalies, were recently observed (Garrabou et al. 2009). During the 2 largest mass mortality events recorded to date (in 1999 and 2003), both in terms of the range of species affected ( 30 species from 5 phyla $)$ and the geographic extent $(\sim 1000 \mathrm{~km}$ of coastline), temperatures reached $\sim 3$ to $4^{\circ} \mathrm{C}$ above average (Cerrano et al. 2000, Garrabou et. al 2009, Crisci et al. 2011). These large events were accompanied by several others, affecting fewer species or being more localized, e.g. in summers of 2006, 2008 and 2009 (Bensoussan et al. 2010, Maldonado et al. 2010, Cebrian et al. 2011, Huete-Stauffer et al. 2011, Stabili et al. 2012). In general, gorgonians, which are structurally important elements of Mediterranean hard-bottom communities, were among the most affected species (Cerrano et al. 2000, Pérez et al. 2000, Garrabou et al. 2009). Several studies assessed the immediate and delayed impacts of these events on gorgonian adult colonies (Linares et al. 2005, Coma et al. 2006, Cupido et al. 2008, 2009, Huete-Stauffer et al. 2011), including sublethal impacts on their reproduction effort (Torrents 2007, Linares et al. 2008a). However, sublethal effects associated with elevated seawater temperature conditions remain poorly studied. The effects of thermal stress on the early life stages of temperate octocorals have not been reported to date.

While it has been argued that sporadic recruitment episodes can ensure the persistence of local populations of a long-lived gorgonian in the absence of strong disturbances (Gotelli 1991, Lasker 1991, Garrabou \& Harmelin 2002, Linares et al. 2007), low survivorship of the early stages would severely limit the recovery if disturbances increased in their magnitude or frequency (Linares et al. 2005, 2008b). In the light of ongoing and expected global warming and the lack of information about the sublethal impacts of thermal stress on octocoral species, it is crucial to investigate the potential impacts of elevated temperature on population dynamics of structural species such as gorgonians.

In this laboratory study, we examined for the first time the effect of thermal stress on the survival, development (embryo to larva) and metamorphosis (larva to polyp) of the red gorgonian Paramuricea clavata (Risso 1826).

\section{MATERIALS AND METHODS}

\section{Study species}

The red gorgonian Paramuricea clavata is an emblematic species of the highly diverse Mediterranean coralligenous communities, playing an important role in the maintenance of biomass and the structural complexity of these habitats (True 1970, Ballesteros 2006). This species is a surface brooder that spawns synchronously every June in 2 to 3 separate episodes, coinciding with the lunar cycle. Fertilization occurs just before eggs are released on the surface of mother colonies or shortly thereafter (Coma et al. 1995, Gori et al. 2007, Linares et al. 2008b). Following holoblastic and equal cleavage, embryos reach the blastula stage after $\sim 24$ h (Linares et al. 2008b). Early pear-shaped planulae appear after $\sim 48$ to $72 \mathrm{~h}$ and become more elongated over time (up to $1 \mathrm{~mm}$ in length). The onset of metamorphosis under laboratory conditions was observed between 8 and $25 \mathrm{~d}$, but this delay may have been caused by a lack of appropriate settlement cues. During metamorphosis, planulae become progressively shorter (reaching an average length of $\sim 550 \mu \mathrm{m}$ ), and their anterior pole displays short tentacles. Developed primary polyps have 8 elongated pinnate tentacles and are $\sim 1.2 \mathrm{~mm}$ long (Fig. 1a-e).

\section{Sampling}

For the laboratory experiments, we obtained eggs from the Medes Islands Marine Protected Area (Northwestern [NW] Mediterranean Sea, 42 $02^{\prime} \mathrm{N}$, $\left.3^{\circ} 13^{\prime} \mathrm{E}\right)$, where Paramuricea clavata populations occur between 15 and $50 \mathrm{~m}$ depth. During the first spawning period of $P$. clavata in June 2010, the eggs were collected by SCUBA divers from the surface of female colonies at $32 \mathrm{~m}$ depth on 16 June 2010. On board, $60 \mathrm{ml}$ syringes containing the eggs were emptied into $250 \mathrm{ml}$ Pyrex ${ }^{\circledR}$ jars and filled with seawater of $\sim 17^{\circ} \mathrm{C}$ (the temperature at the collection depth). Samples were transported in coolers to the Experimental Aquarium Zone of the Institute of Marine Sciences in Barcelona, Spain (within $\sim 4$ h from collection).

\section{Experimental settings}

We carried out 2 separate experiments, wherein we exposed 2 different early developmental stages, eggs and embryos (Expt 1) or larvae (Expt 2), to constant 

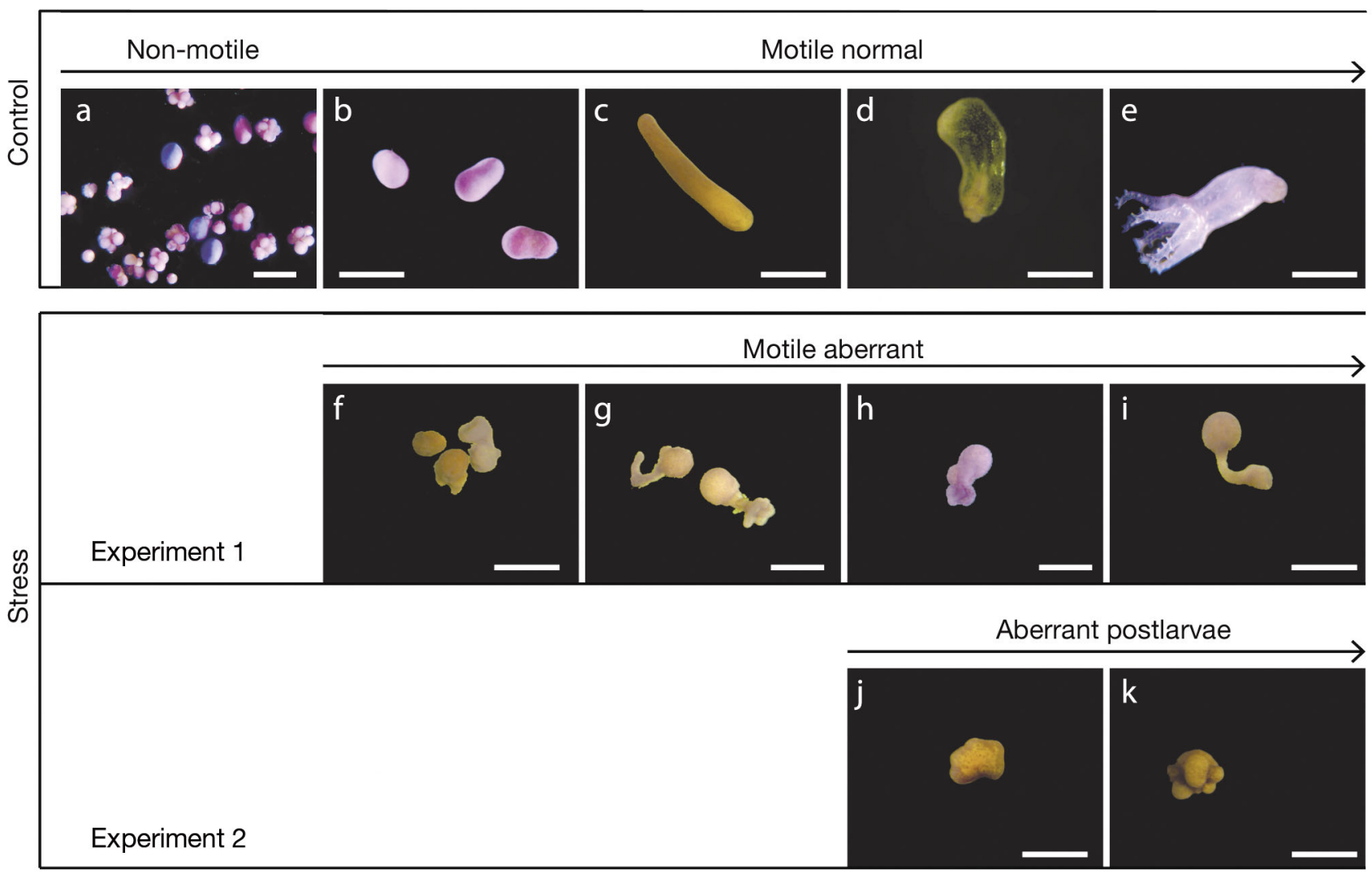

Fig. 1. Paramuricea clavata. Regularly and abnormaly developed early life stages. (a-e) Control: (a) embryos in different developmental stages, (b) early pear-shaped planulae, (c) late planula larva, (d) early metamorphosed stage and (e) primary polyp. (f-i) Aberrant forms after (f-h) $13 \mathrm{~d}$ and (i) $19 \mathrm{~d}$ of thermal stress in Expt 1. (j,k) Aberrant postlarvae after (j) $38 \mathrm{~d}$ and

(k) $51 \mathrm{~d}$ of thermal stress in Expt 2. All scale bars $=500 \mu \mathrm{m}$. Horizontal arrows represent timelines

thermal stress and followed all subsequent modifications and survival over almost 2 mo.

Expt 1. Effects of thermal stress on embryonic and post-embryonic survival and development

Batches of 20 eggs (without previous separation of fertilized and unfertilized eggs) were distributed to 21 Pyrex ${ }^{\circledR}$ jars and filled with 1.51 of filtered seawater (FSW), eliminating particles $>50 \mu \mathrm{m}$. Each jar with 20 eggs was considered a replicate, and 5 replicates each were subjected to the control and the stress treatment (10 jars in total). The controls were exposed to seawater of $\sim 17^{\circ} \mathrm{C}\left(+0.5^{\circ} \mathrm{C}\right.$; ambient temperature during the spawning period), and the stress treatments to $25^{\circ} \mathrm{C}\left( \pm 0.5^{\circ} \mathrm{C}\right)$. This temperature corresponds to the maximum values recorded in the study area (Bensoussan et al. 2010). In addition, this temperature has been recently recorded over prolonged periods during anomalous warm summers (Bensoussan et al. 2010), and previous experiments have shown that it represents the threshold to tissue necrosis in adult colonies of Paramuricea clavata after 3 to $10 \mathrm{~d}$ of exposure (Previati et al. 2010, Crisci et al. 2011). Further, recent climate change scenarios for the end of the 21st century predict an average warming of $+3^{\circ} \mathrm{C}$ for the NW Mediterranean surface waters (Somot et al. 2008, Lasram et al. 2010). Thus $25^{\circ} \mathrm{C}$, selected as the elevated temperature, can be considered a likely warming scenario if we take into account that temperature maxima recorded during the species' reproductive period in June were $\sim 22^{\circ} \mathrm{C}$ at $20 \mathrm{~m}$ depth (T-MedNet temperature records, www.t-mednet.org).

Replicates were kept in water baths (one 481 polycarbonate container per treatment) that were placed in the experimental chamber with the temperature set at $17^{\circ} \mathrm{C}$. In the stress treatment bath, the elevated temperature was maintained by an aquarium heater (250 W, Eheim Jäger) connected to a digital heater controller (T 2001 HC, Aqua Medic), while a pump circulated the water to ensure homogenous temperature conditions among replicates. The temperature 
within the jars was measured daily with a digital thermometer (CheckTemp 1, Hanna ${ }^{\odot}$ ). For the first $20 \mathrm{~d}$ of the experiment, we noted the developmental stage of embryos and their survival in each replicate at intervals of 1 to $2 \mathrm{~d}$, using a stereomicroscope. Later in the experiment, when survival rates became more stable, these variables were quantified at intervals of 2 to $4 \mathrm{~d}$. Following each observation, the water was replaced with FSW of the corresponding temperature.

To document the potential effects of elevated temperature on early embryogenesis, separate batches of eggs were kept in 21 jars in both control and stress treatment baths and sampled after $7 \mathrm{~h}$. Samples were preserved in 3\% glutaraldehyde for subsequent examination using a scanning electron microscope (SEM). Following dehydration through a graded ethanol series, samples were critically point dried from liquid $\mathrm{CO}_{2}$, coated with gold-palladium and examined with a Hitachi S3500N SEM at $10 \mathrm{kV}$.

Since it was not possible to clearly classify aberrant structures that appeared in the stress treatment (see Results) into one of the known developmental stages (described by Linares et al. 2008b), the onset of movement was recorded. Therefore, to maintain the same terminology for comparison of treatments, the following 3 categories were used in Expt 1: 'nonmotile' (including all stages between the egg and late spherical embryo), 'motile' (including all stages between moving early pear-shaped planula and primary polyp) and 'motile aberrant' (including all moving aberrant shapes developed from embryos; Fig. 1).

Expt 2. Effects of thermal stress on larval survival and metamorphosis

Additional batches of eggs were kept at the ambient temperature $\left(17^{\circ} \mathrm{C}\right)$ until larvae developed from the eggs. From these batches, a total of 150 larvae were randomly sampled $11 \mathrm{~d}$ after the collection of eggs in the field. In order to assess the effects of temperature on larval survival and metamorphosis, 75 larvae were subjected to the thermal stress treatment $\left(25^{\circ} \mathrm{C}\right)$, whereas the other 75 were retained under control conditions $\left(17^{\circ} \mathrm{C}\right)$. For the 2 treatments, we prepared 3 replicates with 25 larvae each. Replicates were kept in water baths, and the laboratory conditions and the protocol were the same as described for Expt 1, with water exchanges following each observation. No additional settlement substrate was provided, as settlement cues are still unknown for this species (Linares et al. 2008b). In addition, no specific light conditions were set for the experiments, as: (1) Paramuricea clavata is aposymbiotic (lacking algal symbionts), (2) its larvae are photophobic (Linares et al. 2008b), and (3) temperature was the main factor of interest. However, all replicates during both experiments were exposed to the same dim light conditions.

In the control, the initiation of metamorphosis was determined as a change from swimming or crawling larvae to shortened structures whose anterior poles displayed short tentacles (Linares et al. 2008b). However, in the stress treatment, a change from larvae to abnormal shortened spherical structures (see Results) was termed 'larval modifications', as we could not ascertain whether this change indeed represented the initiation of metamorphosis, or whether larvae simply modified their shape in reaction to stress. To simplify the comparison of treatments by maintaining the same terminology, the categories surveyed in this experiment were defined as 'larvae' and 'postlarvae'. As 'postlarvae' we classified all forms that were morphologically different from initially exposed larvae (Fig. 1c), including attached or non-attached early metamorphosed, shortened stages to primary polyps in the control treatment (e.g. Fig. 1d,e) and modified (but not necessarily metamorphosed) non-attached forms in the stress treatment (e.g. Fig. 1j,k).

\section{Data analysis}

In both experiments, we used survivorship and the timing of development or metamorphosis as response variables. Due to non-normally distributed survival time data, nonparametric methods were applied. From the survival times, we obtained estimates of the survival function for each treatment using the Kaplan-Meier product-limit method (Kaplan \& Meier 1958). Since this analysis cannot accommodate either interval-censored observation (in this case meaning that death occurred within the observation interval but the exact time of death is unknown) or replication, we chose the time when embryos or larvae were last seen alive as the time of death, and we pooled the data from different replicates at a given time for each treatment. The embryos and larvae still alive at the end of the experiment represented censored data, since they did not reach the outcome of interest during the study (i.e. death) and their later survival is unknown. In the analysis, a value of 0 was assigned to these incomplete observations, whereas a value of 1 was assigned to complete observations (i.e. at time points of embryo or larval death during the study). 
To test the differences in survival among treatments, we used the log-rank test, a nonparametric test based on the rank ordering of survival times that can be applied on censored data. A value of $\mathrm{p}<0.05$ was considered significant. All computations were performed using the program STATISTICA (version 8.0, StatSoft).

\section{RESULTS}

\section{Expt 1. Effects of thermal stress on embryonic and post-embryonic survival and development}

The first signs of aberrant development in Paramuricea clavata embryos we observed only $7 \mathrm{~h}$ after exposure to thermal stress. The aberrations were evident in the blastula stage displaying irregularly-sized blastomeres (Fig. 2). The embryo survival in the control was significantly higher than in the stress treatment (Kaplan-Meier survival analysis, log-rank test, $p$ $=0.034$, Fig. 3), although these differences accounted for only 10 to $17 \%$. After $1 \mathrm{~d}$ of the experiment, survival dropped to $75 \%$ in the control and to $64 \%$ in the stress treatment (Fig. 3). Over the next $10 \mathrm{~d}$, the survival was fairly similar in both treatments. In contrast, a clearer difference appeared after $12 \mathrm{~d}$ when $28 \%$ of the embryos had survived in the control, whereas only $11 \%$ in the stress treatment. After $27 \mathrm{~d}$, the survival in the control was $10 \%$ while in the stress treatment it was just $1 \%$, remaining fairly constant during the next month, until the end of the experiment (59 d) (Fig. 3).

In both treatments, the first larvae appeared on the first day of the experiment (observed $54 \mathrm{~h}$ after the collection). By that time, $18 \%$ of embryos remaining in the control treatment developed into motile planula larvae, whereas in the stress treatment only $3 \%$ of embryos $(\mathrm{N}=2)$ developed into normal pearshaped planulae (Fig. 4) that disappeared by the next day. By 5 d, a similar proportion of survived embryos became motile in both the control and the stress treatment (78 and $71 \%$, respectively), and after $6 \mathrm{~d}$ all of the remaining embryos showed clear motility (Fig. 4). However, elevated temperature had a highly detrimental effect on the development of all exposed embryos, resulting in aberrant shapes (Fig. 1f-i) that displayed inefficient, circular movements.

The first metamorphosis in the control was observed after $25 \mathrm{~d}$ of the experiment. After $46 \mathrm{~d}$, all of the remaining larvae were in the process of metamorphosis. At the end of the experiment (59 d), $25 \%$ of the survivors were attached to the bottom of the glass jar. Finally, in the stress treatment, no onset of

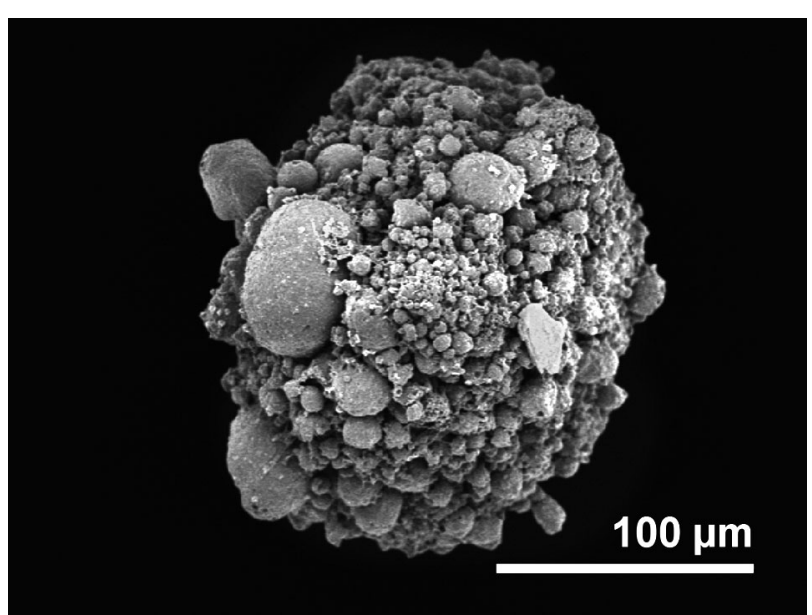

Fig. 2. Paramuricea clavata. Scanning electron micrograph of abnormal blastula after $7 \mathrm{~h}$ of exposure to thermal stress $\left(25^{\circ} \mathrm{C}\right)$. Refer to Linares et al. (2008b) for comparison with normal blastula developed at ambient temperature during the spawning time $\left(\sim 17^{\circ} \mathrm{C}\right)$

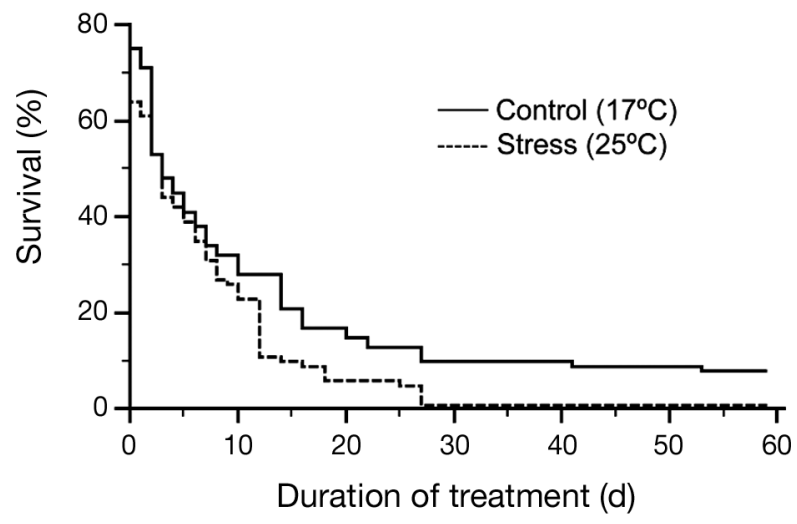

Fig. 3. Paramuricea clavata. Kaplan-Meier estimated survival probabilities for embryos in control $\left(17^{\circ} \mathrm{C}\right.$, initial number $\left.\left[\mathrm{N}_{0}\right]=100\right)$ and under thermal stress $\left(25^{\circ} \mathrm{C}, \mathrm{N}_{0}=100\right)$ (all replicates pooled). At time 0 , survival is already $<100 \%$ since that was the presumed time of death of embryos assessed as missing on Day 1 of treatment (i.e. they were last seen alive at time 0 ; see explanation of survival calculation in 'Materials and methods')

metamorphosis could be detected, probably due to the highly aberrant development observed.

\section{Expt 2. Effects of thermal stress on larval survival and metamorphosis}

Similar to the first experiment and despite the high initial survival in both treatments, larval survival over time was significantly higher in the control than in the stress treatment (Kaplan-Meier survival analysis, log-rank test, $p=0.008$, Fig. 5). During the first $27 \mathrm{~d}$, 


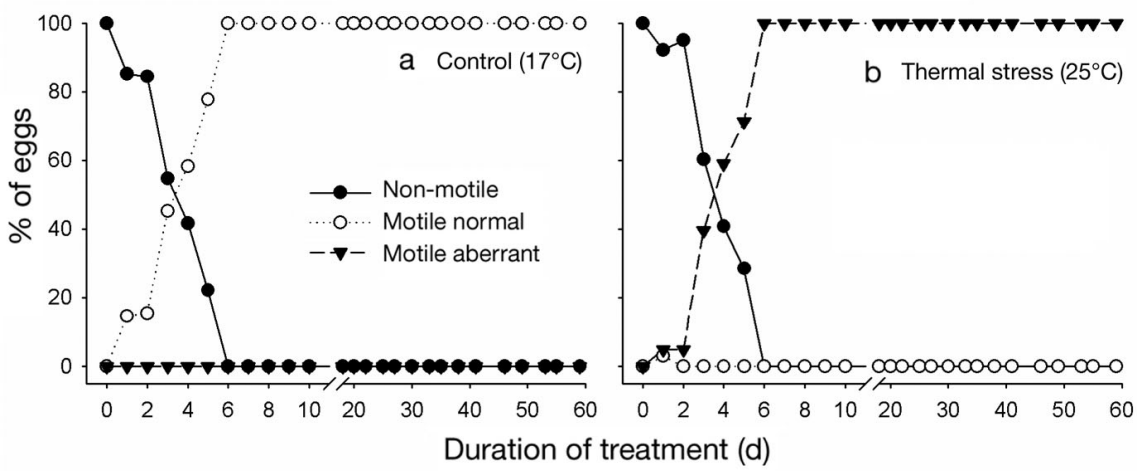

Fig. 4. Paramuricea clavata. Development of embryos in the laboratory. (a) Control $\left(17^{\circ} \mathrm{C}, \mathrm{N}_{0}=100\right)$ and (b) thermal stress $\left(25^{\circ} \mathrm{C}, \mathrm{N}_{0}=100\right)$. The results are based on a rapidly reduced number of survivors (refer to Fig. 3)

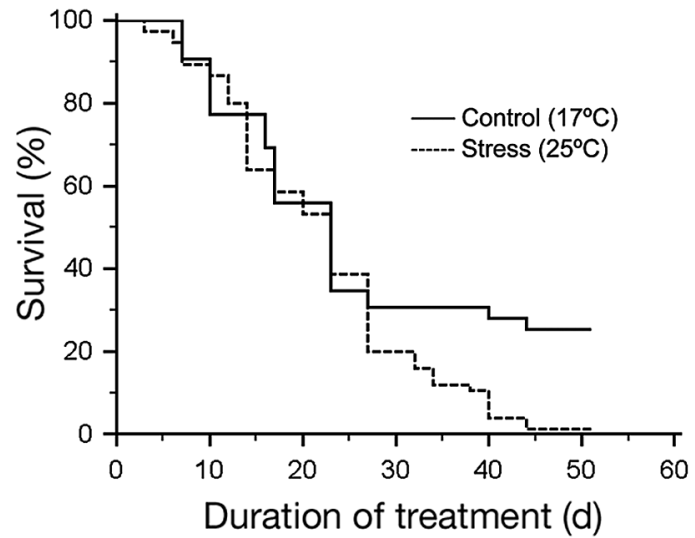

Fig. 5. Paramuricea clavata. Kaplan-Meier estimated survival probabilities for larvae in control $\left(17^{\circ} \mathrm{C}, \mathrm{N}_{0}=75\right)$ and under thermal stress $\left(25^{\circ} \mathrm{C}, \mathrm{N}_{0}=75\right)$ (all replicates pooled). Treatment started $11 \mathrm{~d}$ after collection of eggs in the field

larval survival in the control and the stress treatment showed similar trends with a reduction to $\sim 40 \%$ (Fig. 5). After $27 \mathrm{~d}$, the differences between treatments clearly increased. Survival dropped from 20 to just $1.33 \%$ in the stress treatment, whereas it decreased only slightly to $30 \%$ in the control, remaining fairly constant until the end of the experiment (Fig. 5).

The first larva undergoing modifications in the stress treatment was noted after $10 \mathrm{~d}$ (Fig. 6). On Day 17, when metamorphosis started in the control, $92 \%$ of larvae in the stress treatment had already modified. After $20 \mathrm{~d}, 60 \%$ of the surviving larvae in the control had metamorphosed in comparison to $98 \%$ that were modified in the stress treatment (Fig. 6). However, as a result of a stress response, all larvae modified into spherical, aberrant shapes compromising the proper metamorphosis (Fig. 1j,k). Later postlarval stages with developed tentacles were never attained, and attachment to the substrate (bottom of the glass jars) was never noted. After $23 \mathrm{~d}$, no larval stages were present in the stress treatment, whereas $40 \%$ of survivors were still in the larval stage in the control (Fig. 6). At the end of the experiment (51 d), 1 aberrant postlarva was still present in the stress treatment. In the control $(\mathrm{N}=19), 11 \%$ of the survivors were in the larval stage, $32 \%$ in the more advanced stage of metamorphosis with developed short non-pinnated tentacles, and $58 \%$ in the primary polyp stage. Out of these, 1 primary polyp settled on the bottom of the glass jar.

\section{DISCUSSION}

We present the first attempt to assess the response of early life stages of a gorgonian to thermal stress. The elevated temperature used in the experiments corresponds to the maximum summer values already recorded in the study area (Crisci et al. 2011) and represents the temperature that is $\sim 3^{\circ} \mathrm{C}$ above the maximum temperature recorded at $20 \mathrm{~m}$ depth during the reproductive period of the red gorgonian Paramuricea clavata $\left(\sim 22^{\circ} \mathrm{C}\right.$, T-MedNet temperature records, www.t-mednet.org), simulating the predicted warming by the end of the 21st century in the NW Mediterranean (Somot et al. 2008). Our study showed a severe negative effect of such constant elevated temperature on the embryos and larvae of $P$. clavata, resulting in significantly reduced survivorship, completely abnormal embryonic development and impaired metamorphosis.

\section{Expt 1. Effects of thermal stress on embryonic and post-embryonic survival and development}

The normal embryonic development of Paramuricea clavata is characterized by holoblastic and equal cleavage (Linares et al. 2008b) resulting in equallysized blastomeres. In contrast, the exposure to thermal stress for $7 \mathrm{~h}$ resulted in aberrant blastulae with irregularly-sized blastomeres (Fig. 2). It was not pos- 


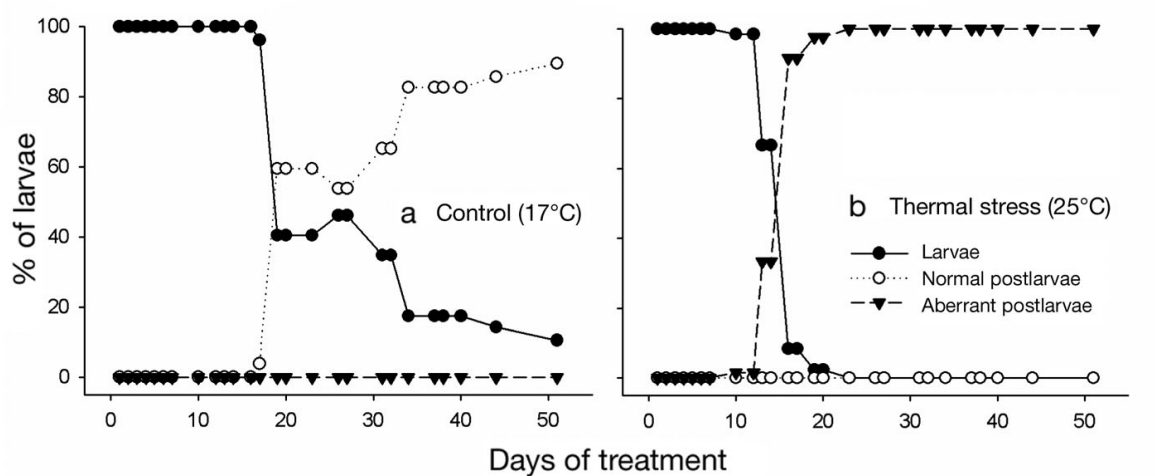

Fig. 6. Paramuricea clavata. Metamorphosis of larvae in the laboratory at (a) control $\left(17^{\circ} \mathrm{C}, \mathrm{N}_{0}=75\right)$ and (b) under thermal stress $\left(25^{\circ} \mathrm{C}, \mathrm{N}_{0}=75\right)$. The apparent increase in the \% of larvae on Days 26 and 27 in the control is an artifact by higher mortality of normal postlarvae than larvae at this time point (refer also to Fig. 5). Beyond $34 \mathrm{~d}$ of the stress treatment, the results are based on $<10$ aberrant postlarvae sible to quantify with certainty the proportion of aberrant early-stage embryos due to the presence of different embryonic stages at the time of collection in the field (preceding and following blastula stages) and their inconspicuous aberrations if present. However, this observation suggests that even a very short exposure to the elevated temperature may have a detrimental effect on the embryonic development. More than $1 \mathrm{~d}$ of exposure to the elevated temperature resulted in unequivocal developmental failures in all embryos reaching motility, evident as aberrant, inefficiently moving shapes and coinciding with reduced survivorship over time (Figs. 2 \& 3). In previous studies, abnormal embryonic coral development at elevated temperatures was noted both for the early stage (until the 5th cell cleavage, Negri et al. 2007) as well as for the later-stage embryos (Bassim et al. 2002, Randall \& Szmant 2009b) followed by a reported decrease in survival (e.g. Randall \& Szmant 2009b). A possible mechanism behind these observed detrimental effects on embryos may be down-regulation of genes involved in crucial cellular processes such as cell replication or division, metabolism, cytoskeleton reorganisation and transcription, as suggested by Portune et al. (2010) for abnormal embryonic development of the scleractinian coral Acropora palmata exposed to hyperthermal stress.

Initial mortality was high in both treatments, but the survival of embryos was always higher in the controls than at the elevated temperature. Since decreased survival after $1 \mathrm{~d}$ of the experiment (Fig. 3) was in concordance with the fertilization rates previously noted both in the laboratory and the field ( $\sim 60$ to $69 \%$; Linares et al. 2008b), this initial mortality in both treatments could, at least partially, be attributed to the decay of unfertilized eggs. By Day 5 of the experiment, the survival was already $<50 \%$ in both treatments (Fig. 3). To date, high initial rates of mortality have been observed in several coral species reared in ambient laboratory conditions and potentially attributed to developmental failures, unequal provisioning of offspring by parents, densitydependent mortality or handling effects (e.g. Graham et al. 2008, Connolly \& Baird 2010). While some of these factors may have initially acted in the control treatment, it seems they were further exacerbated by temperature-induced abnormal development in the stress treatment, resulting in even lower survival.

\section{Expt 2. Effects of thermal stress on larval survival and metamorphosis}

The survival of Paramuricea clavata larvae exposed to elevated temperature was significantly reduced over time (Fig. 5), as previously reported for some scleractinian corals (e.g. Bassim \& Sammarco 2003, Brooke \& Young 2005). However, initial larval survival was high, and at the end of the experiment (51 d) there was still 1 live aberrant postlarva present in the stress treatment. Similarly, high larval survival $(>60 \%$ ) of the scleractinian coral Oculina varicosa was recorded even after $23 \mathrm{~d}$ of exposure to elevated temperature (Brooke \& Young 2005). Recently, the current understanding of larval energetics was challenged by Graham et al. (2008), who reported unexpectedly long lifespans (ranging from 195 to $244 \mathrm{~d}$ ) of several lecithotrophic scleractinian coral larvae reared under laboratory conditions. Generally, long survival of larvae implies the availability of large initial energy reserves that the larva is either able to supplement during its life, e.g. via symbiotic zooxanthellae or potentially even through the uptake of dissolved organic matter (DOM), or that it is able to control its metabolic rates (Richmond 1987, Manahan 1990, Ben-David-Zaslow \& Benayahu 2000, Harii et al. 2007, Okubo et al. 2008). The red gorgonian $P$. clavata is aposymbiotic and there is no evidence of DOM uptake by its larvae, although the latter cannot be excluded. However, we observed reduced swim- 
ming of larvae exposed to thermal stress for several days, compared with the ones at control temperature, and this has been suggested previously as a means of energy conservation (e.g. Graham et al. 2008).

In both treatments, postlarvae appeared within the upper time span previously observed for metamorphosis under laboratory conditions (Linares et al. 2008b) or, in some cases, exceeding it by almost double (Fig. 6). This could be attributed to the lack of appropriate settlement cues. However, observed modifications of larvae exposed to thermal stress progressed faster. Modifications of these larvae started $7 \mathrm{~d}$ earlier than metamorphosis in the control, and by the time the metamorphosis started in the control, $92 \%$ of larvae exposed to thermal stress had already undergone modifications (Fig. 6). The increase in the metamorphosis rate as an effect of elevated temperature was observed previously (e.g. Edmunds et al. 2001, Nozawa \& Harrison 2007, Heyward \& Negri 2010). However, in the stress treatment of our study, if the metamorphosis was initiated in the first place, it was triggered earlier but it was severely compromised. All larvae exposed to elevated temperature attained aberrant spherical shapes and never attached or displayed any similarity to the morphology of polyps. Likewise, other studies reported the appearance of aberrant larval forms under elevated temperature conditions (Randall \& Szmant 2009a,b).

\section{Comparison of the thermal stress response of Paramuricea clavata embryos versus larvae}

While the thermal stress of $25^{\circ} \mathrm{C}$ proved to be highly detrimental for the embryo stage, resulting in rapid negative effects on development, the immediate effect on the larval stage was not so evident. Initially exposed P. clavata larvae demonstrated high survivorship without clear external negative effects (up to $10 \mathrm{~d}$ when the first aberrant postlarvae appeared). A severe impact became evident only later in the larval life. This outcome suggests that thermal stress exposure during embryonic development may be most critical for the viability of $P$. clavata larvae, as also observed for several reefbuilding corals (Heyward \& Negri 2010).

\section{Potential consequences of global warming on early life stages of Paramuricea clavata}

The experimentally elevated temperature corresponded to the present-day maximum summer val- ues recorded in the study area, whereas in some other parts of the NW Mediterranean harboring P. clavata populations (e.g. Scandola in Corsica), these temperatures are even higher and have already reached $27.9^{\circ} \mathrm{C}$ (Crisci et al. 2011). In the NW Mediterranean, over the past 3 decades regional warming of coastal waters by $\sim 1^{\circ} \mathrm{C}$ has been documented (Salat \& Pascual 2002, Bensoussan et al. 2009). This warming trend has caused a $40 \%$ (i.e. 40 d) increase in the time during which $P$. clavata populations are exposed to summer conditions, correlating with an increase of $\sim 1.5^{\circ} \mathrm{C}$ in maximum monthly summer temperature at $20 \mathrm{~m}$ in the study area (Coma et al. 2009). In addition, it is indicative that the highest temperatures during June in the study area were recorded recently, within the last $10 \mathrm{yr}\left(22.3^{\circ} \mathrm{C}\right.$ in $2003,22.4^{\circ} \mathrm{C}$ in 2006 and $2009, \mathrm{~T}$ MedNet, www.t-mednet.org). These records were followed by exceptionally warm summers with temperatures reaching $>25^{\circ} \mathrm{C}$, resulting in local (in 2006) or larger-scale (in 2003) mass mortality events of adult colonies in other parts of the NW Mediterranean (Garrabou et al. 2009, Crisci et al. 2011). The detrimental elevated temperature used in our study has not yet been recorded during the main spawning events of P. clavata in June. However, it may occur in the future, either as a consequence of the predicted warming trend by the end of the century (Somot et al. 2008) or as a result of a shift of positive temperature anomalies from late to early summer, as occurred during the 2006 anomaly (Bensoussan et al. 2010). Any future change that would shift positive thermal anomalies even earlier in summer could have a negative impact on the viability of $P$. clavata early life stages. For embryos, as suggested by our results, even short positive anomalies that have been already recorded in the NW Mediterranean (lasting 2 to $5 \mathrm{~d}$, Crisci et al. 2011) would be detrimental.

Since asexual reproduction is considered negligible for temperate gorgonian species, successful sexual reproduction is of major importance for the replenishment of populations (Coma et al. 1995). Hence, the reduced viability of Paramuricea clavata early life stages would decrease recruitment and thus affect the long-term persistence of shallow populations.

Beyond the direct negative effect of high temperatures on early life stages, another potential effect of future warming may be an earlier spring rise in water temperature. This may lead to the subsequent modification of the Paramuricea clavata reproductive period, as temperature rise and lunar phase are considered to be the main triggers for spawning (Coma et al. 1995, Linares et al. 2008b). Longer-term observa- 
tions of the P. clavata reproductive cycle, accompanied by continued temperature data acquisition, may enable detection of such changes in this species. To date, a modification of the reproductive period has already been documented for Mediterranean hydrozoans, and it has been suggested as a useful trait in the assessment of global warming impacts (Puce et al. 2009).

In conclusion, further investigation of the effects of thermal stress (as well as of other anthropogenic stressors, acting individually or in synergy) on the reproduction of structural species and the viability of their early life stages will improve our understanding of the long-term consequences of environmental global change in marine benthic communities.

Acknowledgements. We thank J. M. Fortuño for assistance with scanning electronic microscopy, the Medes Islands MPA Staff for their continuous support, and O. Ross and M. Buklijas Caleta for help in image editing. We further thank the 3 anonymous reviewers for their constructive comments. S.K. acknowledges Research Fellowship 2009-11 from the Spanish Agency for International Development Cooperation (AECID). This study was funded by the Spanish Ministry of Science and Innovation (Biorock project ref. CTM2009-08045), Juan de la Cierva and Ramon y Cajal contracts to C.L. and Beatriu de Pinós contract to N.T. This is a contribution from the Medrecover research group, funded by the Generalitat de Catalunya (Catalan Government).

\section{LITERATURE CITED}

Ballesteros E (2006) Mediterranean coralligenous assemblages: a synthesis of present knowledge. Oceanogr Mar Biol Annu Rev 44:123-195

Bassim K, Sammarco P (2003) Effects of temperature and ammonium on larval development and survivorship in a scleractinian coral (Diploria strigosa). Mar Biol 142:241-252

Bassim K, Sammarco P, Snell T (2002) Effects of temperature on success of (self and non-self) fertilization and embryogenesis in Diploria strigosa (Cnidaria, Scleractinia). Mar Biol 140:479-488

Ben-David-Zaslow R, Benayahu Y (2000) Biochemical composition, metabolism, and amino acid transport in planula-larvae of the soft coral Heteroxenia fuscescens. J Exp Zool 287:401-412

Bensoussan N, Romano JC, Harmelin JG, Crisci C, Pascual J, Garrabou J (2009) Warming trends, regional fingerprints and future trajectories of NW Mediterranean coastal waters. In: Pergent-Martini C, Brichet M (eds) Proc 1st Mediterr Symp Conserv Coralligenous and other Calcareous Bio-concretions. RAC/SPA, Tunis, p 167-168

Bensoussan N, Romano JC, Harmelin JG, Garrabou J (2010) High resolution characterization of northwest Mediterranean coastal waters thermal regimes: to better understand responses of benthic communities to climate change. Estuar Coast Shelf Sci 87:431-441

Brooke S, Young CM (2005) Embryogenesis and larval biology of the ahermatypic scleractinian Oculina varicosa. Mar Biol 146:665-675
Cebrian E, Uriz MJ, Garrabou J, Ballesteros E (2011) Sponge mass mortalities in a warming Mediterranean sea: Are cyanobacteria-harboring species worse off? PLoS ONE 6: e20211

> Cerrano C, Bavestrello G, Bianchi CN, Cattaneo-Vietti R and others (2000) A catastrophic mass-mortality episode of gorgonians and other organisms in the Ligurian Sea (northwestern Mediterranean), summer 1999. Ecol Lett 3:284-293

> Coma R, Ribes M, Zabala M, Gili JM (1995) Reproduction and cycle of gonadal development in the Mediterranean gorgonian Paramuricea clavata. Mar Ecol Prog Ser 117: 173-183

> Coma R, Linares C, Ribes M, Diaz D, Garrabou J, Ballesteros E (2006) Consequences of a mass mortality in populations of Eunicella singularis (Cnidaria: Octocorallia) in Menorca (NW Mediterranean). Mar Ecol Prog Ser 327: $51-60$

> Coma R, Ribes M, Serrano E, Jiménez E, Salat J, Pascual J (2009) Global warming-enhanced stratification and mass mortality events in the Mediterranean. Proc Natl Acad Sci USA 106:6176-6181

> Connolly S, Baird A (2010) Estimating dispersal potential for marine larvae: dynamic models applied to scleractinian corals. Ecology 91:3572-3583

Crisci C, Bensoussan N, Romano JC, Garrabou J (2011) Temperature anomalies and mortality events in marine communities: insights on factors behind differential mortality impacts in the NW Mediterranean. PLoS ONE 6: e23814

Cupido R, Cocito S, Sgorbini S, Bordone A, Santangelo G (2008) Response of a gorgonian (Paramuricea clavata) population to mortality events: recovery or loss? Aquatic Conserv 18:984-992

> Cupido R, Cocito S, Barsanti M, Sgorbini S, Peirano A, Santangelo G (2009) Unexpected long-term population dynamics in a canopy-forming gorgonian coral following mass mortality. Mar Ecol Prog Ser 394:195-200

Edmunds PJ, Gates RD, Gleason FD (2001) The biology of larvae from the reef coral Porites astreoides, and their response to temperature disturbances. Mar Biol 139: 981-989

- Edmunds PJ, Cumbo V, Fan T (2011) Effects of temperature on the respiration of brooded larvae from tropical reef corals. J Exp Biol 214:2783-2790

> Garrabou J, Harmelin JG (2002) A 20-year study on life-history traits of a harvested long-lived temperate coral in the NW Mediterranean: insights into conservation and management needs. J Anim Ecol 71:966-978

> Garrabou J, Coma R, Bensoussan N, Bally M and others (2009) Mass mortality in Northwestern Mediterranean rocky benthic communities: effects of the 2003 heat wave. Glob Change Biol 15:1090-1103

Giorgi F (2006) Climate change hot-spots. Geophys Res Lett 33:L08707, doi:10.1029/2006GL025734

> Gori A, Linares C, Rossi S, Coma R, Gili JM (2007) Spatial variability in reproductive cycle of the gorgonians Paramuricea clavata and Eunicella singularis (Anthozoa, Octocorallia) in the Western Mediterranean Sea. Mar Biol 151:1571-1584

> Gotelli NJ (1991) Demographic models for Leptogorgia virgulata, a shallow-water gorgonian. Ecology 72:457-467

> Graham EM, Baird AH, Connolly SR (2008) Survival dynamics of scleractinian coral larvae and implications for dispersal. Coral Reefs 27:529-539 
Halpern BS, Walbridge S, Selkoe KA, Kappel CV and others (2008) A global map of human impact on marine ecosystems. Science 319:948-952

Harii S, Nadaoka K, Yamamoto M, Iwao K (2007) Temporal changes in settlement, lipid content and lipid composition of larvae of the spawning hermatypic coral Acropora tenuis. Mar Ecol Prog Ser 346:89-96

- Heyward AJ, Negri AP (2010) Plasticity of larval pre-competency in response to temperature: observations on multiple broadcast spawning coral species. Coral Reefs 29: 631-636

> Huete-Stauffer C, Vielmini I, Palma M, Navone A and others (2011) Paramuricea clavata (Anthozoa, Octocorallia) loss in the Marine Protected Area of Tavolara (Sardinia, Italy) due to a mass mortality event. PSZNI: Mar Ecol 32: 107-116

> Kaplan EL, Meier P (1958) Non-parametric estimation from incomplete observations. J Am Stat Assoc 53:457-481

> Lasker HR (1991) Population growth of a gorgonian coral: equilibrium and non-equilibrium sensitivity to changes in life history variables. Oecologia 86:503-509

> Lasram FBR, Guilhaumon F, Albouy C, Somot S, Thuiller W, Mouillot D (2010) The Mediterranean Sea as a 'cul-de-

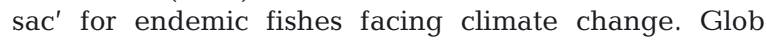
Change Biol 16:3233-3245

- Linares C, Coma R, Diaz D, Zabala M, Hereu B, Dantart L (2005) Immediate and delayed effects of a mass mortality event on gorgonian population dynamics and benthic community structure in the NW Mediterranean Sea. Mar Ecol Prog Ser 305:127-137

> Linares C, Doak DF, Coma R, Díaz D, Zabala M (2007) Life history and viability of a long-lived marine invertebrate: the octocoral Paramuricea clavata. Ecology 88:918-928

Linares C, Coma R, Zabala M (2008a) Effects of a mass mortality event on gorgonian reproduction. Coral Reefs 27: 27-34

Linares C, Coma R, Mariani S, Díaz D, Hereu B, Zabala M (2008b) Early life history of the Mediterranean gorgonian Paramuricea clavata: implications for population dynamics. Invertebr Biol 127:1-11

Maldonado M, Sànchez-Tocino L, Navarro C (2010) Recurrent disease outbreaks in corneous demosponges of the genus Ircinia: epidemic incidence and defence mechanisms. Mar Biol 157:1577-1590

Manahan DT (1990) Adaptations by invertebrate larvae for nutrient acquisition from seawater. Am Zool 30: $147-160$

> Negri AP, Marshall PA, Heyward AJ (2007) Differing effects of thermal stress on coral fertilization and early embryogenesis in four Indo Pacific species. Coral Reefs 26: 759-763

> Nozawa Y, Harrison PL (2007) Effects of elevated temperature on larval settlement and post-settlement survival in scleractinian corals, Acropora solitaryensis and Favites chinensis. Mar Biol 152:1181-1185

> Okubo N, Yamamoto HH, Nakaya F, Okaji K (2008) Oxygen consumption of a single embryo/planula in the reefbuilding coral Acropora intermedia. Mar Ecol Prog Ser 366:305-309

Pérez T, Garrabou J, Sartoretto S, Harmelin JG, Francour P, Vacelet J (2000) Mass mortality of marine invertebrates: an unprecedented event in the Northwestern Mediter-

Editorial responsibility: Charles Birkeland,

Honolulu, Hawaii, USA ranean. C R Acad Sci Serie III Sci Vie 323:853-865

Polato NR, Voolstra CR, Schnetzer J, DeSalvo MK and others (2010) Location-specific responses to thermal stress in larvae of the reef-building coral Montastraea faveolata. PLoS ONE 5:e11221

Portune KJ, Voolstra CR, Medina M, Szmant AM (2010) Development and heat stress-induced transcriptomic changes during embryogenesis of the scleractinian coral Acropora palmata. Mar Genomics 3:51-62

> Previati M, Scinto A, Cerrano C, Osinga R (2010) Oxygen consumption in Mediterranean octocorals under different temperatures. J Exp Mar Biol Ecol 390:39-48

> Puce S, Bavestrello G, Di Camillo CG, Boero F (2009) Longterm changes in hydroid (Cnidaria, Hydrozoa) assemblages: effect of Mediterranean warming? PSZNI: Mar Ecol 30:313-326

Putnam HM, Edmunds PJ, Fan TY (2008) Effect of temperature on the settlement choice and photophysiology of larvae from the reef coral Stylophora pistillata. Biol Bull (Woods Hole) 215:135-142

Randall CJ, Szmant AM (2009a) Elevated temperature reduces survivorship and settlement of the larvae of the Caribbean scleractinian coral, Favia fragum (Esper). Coral Reefs 28:537-545

Randall CJ, Szmant A (2009b) Elevated temperature affects development, survivorship, and settlement of the elkhorn coral, Acropora palmata (Lamarck 1816). Biol Bull (Woods Hole) 217:269-282

Richmond RH (1987) Energetics, competence, and longdistance dispersal of planula larvae of the coral Pocillopora damicornis. Mar Biol 93:527-533

Rodriguez-Lanetty M, Harii S, Hoegh-Guldberg O (2009) Early molecular responses of coral larvae to hyperthermal stress. Mol Ecol 18:5101-5114

Salat J, Pascual J (2002) The oceanographic and meteorological station at l'Estartit (NW Mediterranean). In: Briand F (ed) Tracking long-term hydrological change in the Mediterranean Sea. CIESM Workshop Series, CIESM, Monaco, p 29-32

> Somot S, Sevault F, Déqué M, Crépon M (2008) 21st century climate change scenario for the Mediterranean using a coupled atmosphere-ocean regional climate model. Global Planet Change 63:112-126

Stabili L, Cardone F, Alifano P, Tredici SM, Piraino S, Corriero G, Gaino E (2012) Epidemic mortality of the sponge Ircinia variabilis (Schmidt, 1862) associated to proliferation of a Vibrio bacterium. Microb Ecol 64:802-813

Torrents O (2007) Biologie des populations du corail rouge Corallium rubrum (L. 1758) de Méditerrané nord-occidentale. PhD dissertation, Université de la Méditerranée, Marseille

True MA (1970) Étude quantitative de quatre peuplements sciaphiles sur substrat rocheurs dans la région marseillaise. Bull Inst Ocèanogr Monaco 60:1-41

- Voolstra CR, Schnetzer J, Peshkin L, Randall CJ, Szmant AM, Medina M (2009) Effects of temperature on gene expression in embryos of the coral Montastraea faveolata. BMC Genomics 10:627

Zeevi-Ben-Yosef D, Benayahu Y (2008) Synergistic effects of UVR and temperature on the survival of azooxanthellate and zooxanthellate early developmental stages of soft corals. Bull Mar Sci 83:401-414

Submitted: March 21, 2012; Accepted: August 5, 2012 Proofs received from author(s): November 12, 2012 